\title{
ASPECTS OF MORAL UPBRINGING IN EDUCATIONAL PROCESS OF FUTURE PHARMACISTS
}

Morality, as a form of social consciousness, is a set of principles, requirements, norms and rules that regulate human behavior in all spheres of professional and social life. The article deals with aspects of moral education and personality traits of the future pharmacist. The moral development of future pharmacists involves not only the assimilation of norms, but also the standardization, the degree and nature of which may be a criterion for the level of moral self-activity. The above fact cannot but change the understanding of the very essence of moral upbringing, as well as one of its essential manifestations - a moral choice. The content and tasks of moral education are defined, the complex of moral and ethical qualities of future specialists, which are formed in the process of professional training, is characterized, features of moral motivation of future pharmacists are determined. The author of the article offers and analyzes educational technologies for the formation of professional moral upbringing.

Key words: morality, mannerliness, self-activity, social intelligence, criteria of moral upbringing.

Formulation of the problem. Significant socio-economic changes of our society, as well as attempts of Ukraine to get into European educational space found its way into the system of medical education: the structure of it changes, standards get updated. The growth of importance of humanistic values in modern medical education requires an increase in the ethical orientation of students and a radical change in existing criterial approaches to the general education system of future pharmacists.

Nowadays society comes to terms with the fact that for a full-fledged development of personality it is not enough to form in it only a scientific picture of the world, which, though fully and holistic reflects the knowledge and representation of people surrounding its environment, but does not defile them, makes only the mind, not soul. Therefore, moral education is the most complicated link in the general educational process. It is least subject to direct regulation and, at the same time, the most sensitive to the general state of affairs in society, is most closely connected with the traditions of this society and the real prospects for its further development. Among a large range of problems of moral education, which have intensified lately, the definition of aspects of moral education of future pharmacists occupies a special place. Moreover, at the moment there was a problem of human humanization, that is, the problem of making a person more responsive, conscientious and humane. This also applies to future pharmacists, because their activities - a social phenomenon, which is carried out on the basis of conscience, in particular.

Analysis of the latest researches. Problem of moral upbringing was and is an object of study of many different sciences and their representatives. Methodological aspect was researched by members of modern philosophy (S. Borovyk, V. Varyuhin, I. Zyazyun, P. Kolychev, M. Ryabov, O. Savhenko and others). Some educationalists (E. Bondarevska, T. Golovan, V. Vodzynskiy, L. Koval, M. Monahov) emphasized the dominance of an active professional aspect, which allows to bring in humanity into field of activity of future pharmacists. Some scientific works are dedicated to behavior standards of pharmacy workers (N. Alyohina, L. Galiy, O. Kotovska and others). The focus on the culture of pharmacists is reflected in the trends of modern medical education institutions, such as: humanitarian and humanist orientation, personal attitude, creation of real start-up opportunities for future pharmacists for the purpose of their life self-determination. The development of ethical declaration of pharmacists is covered in works of A. Babskiy, T. Krasnyanska, M, Ponomarenko, $\mathrm{O}$, Ternova, V. Trohymchuk and others. The desire to understand the nature of the pharmacist's constructive thinking led to the emergence of many judgments, thoughts, theories, concepts in domestic psychology (N. Belkania, A. Kovalenko, N. Kryvokon, V. Panok, T. Sergeeva, O. Timchenko, L. Shestopalova and others). Problems of social effect of pharmacists were researched by V. Vlasova, E. Volska, Y. Lopuhina, P. Lopatina, V. Petrova, N. Sedova, B. Yudina and others. Directions of motivation of the pharmacist as a conductor of bioethics in pharmaceutical practice were studied by O. Gryshenko, V. Kulinichenko, M. Petrenko and others.

Purpose of the article is to unfold aspects of moral education of pharmacists and educational technologies for the formation of professional moral upbringing. In our opinion, the moral education of the future pharmacist can be marked as integral quality, characterized by the degree of formation of socially significant moral qualities that form the result of the mechanism of internal value-normative regulation of the behavior of the person and his external moral relations, manifested in the activity and communication.

Presentation of the main material. Pharmacist is a specialist with a higher education who has the right to conduct independent pharmaceutical work, they must know the physical and chemical properties of medicines, 
provide advisory assistance to the population on the use of medicines, should be fundamental, highly professional, and be an irreplaceable partner of clients. (O. Ternov). Specificity of pharmacist's work requires prompt action, balance; and the main indicator of this is the psychological state, which is largely determined by the nature of interaction with clients. That is, the presence of internal anxiety, or, on the contrary, rest, are indicators of the moral and psychological state of the pharmacist. According to L. Koval, the moral foundation is the core on which any manifestations of human activity should be based, which will become the basis for the development of all other aspects of the personality.

A person, whatever the broad knowledge about the world they have, however deeply they understand the laws of social development, will not be able to become a true expert in the pharmacology, unless they draw upon the norms and requirements of morality. Naturally, because of this, the question of objective criteria of morality arises, answering which makes it possible to draw a solution to the key problem of human life: what is good and what separates it from evil.

The scientific approach to this problem involves the diagnosis of general upbringing of the individual. It should be noted, that the diagnosis can be carried out through a variety of psychodiagnostic techniques (conversations, questionnaires, psychological counseling, round tables, etc.). The methods described above will help us to fully assess the nature and characteristics of the communication process, professionalism, knowledge, skill. In our opinion, it is psychological counseling that provides the creation of favorable conditions to master one's own experiences and find rational ways of action. No less important is the question of the effectiveness of psychological counseling, when these subjective factors are taken as basis: the state of health of the client, his satisfaction with the process of communication, the belief that the pharmacist can help in solving a certain problem.

The phenomenon of moral upbringing of future pharmacists differs in great complexity and is considered in various aspects. Mannerliness is the most important psycho-pedagogical and socio-pedagogical characteristic of a person, it is closely connected with all aspects of life, reflects the degree of comprehensiveness and harmony. Moral upbringing, as N. Alehina notes, is a special form of internal self-activity, 'social intelligence', which allows future pharmacists to establish moral value in relation to a particular situation, to create new forms of communication, to act as the initiator of new effective forms of social interaction [1]. Understanding the nature of activity, as self-activity, allows individual people who do not possess significant ethical or legal knowledge, to respond unmistakably to the moral content of a situation that is often hidden behind the nice and correct forms of instant relationships. Based on the understanding of moral upbringing, we drew attention to the internal valuenormative regulation of a person, which reflects the micro-world of future pharmacists, namely natural qualities, the ultimate result of which are social and moral actions-attitudes.

Each psychological problem has its stages, which are caused by uncertainty, spontaneity, unpredictability, and also determinants that have corresponding causes and regularities. Finding ways to overcome their increased impact is an important factor in the successful resolution of the problem. The psychological problem in communication has two sides: the client's problem and the problem of pharmacist. The client's problem is a certain psychological disharmony, an unfavorable behavioral complex that creates psychological difficulties that cause emotional worries. This is often a feeling of dissatisfaction with oneself or another person. The task of the pharmacist is to seek ways to provide psychological assistance to the client. When communicating with a client, the pharmacist solves two main tasks: helps them to understand their own problems, to find a radical way to overcome them and to actualize the psychological forces and capabilities that will assist in solving the problem. Therefore, first and foremost, we choose an advisory conversation as the main method of counseling. It can have two aspects: diagnostic and psychotherapeutic.

As a part of the diagnostic aspect, it is necessary for pharmacist to identify the problem, to find out the causes and sources of its origin, as detailed study of the starting moments of contact are crucial for initial communication during first minutes. During this time unconscious but strategically important decisions are made concerning the further contact. The first impressions, as O. Bondarenko notes, are bright enough, impressive and extremely remarkable for future communication [2]. Since a person exists only in the system of relations with another person, and the first one has to treat the other as himself, then the task of the initial consultative conversation should be as follows: obtaining customer loyalty, relieving the tension, establishing contact, encouraging the discussion about problem, formation of realistic expectations about mutual work. Furthermore, pharmacist should be knowledgeable about variety of new pharmaceutical technologies, have his own opinion, be able to inform the client of it, while giving great importance to voice, timbre, mimicry, manners, gestures, and glances in order to make a responsible decision and gain credibility. An important task for future pharmacists is to encourage the client to talk about their problems. Questions about the state of the client, his well-being in a counseling environment also help to relieve tension. It is important for future pharmacists to feel the needs, experiences, aspirations of the person. The first meeting with the client allows future pharmacist to understand how far they are ready for further work in this area. Insufficient reflection, low motivation can prevent the first positive steps towards effective work. Scientists Greenson, Raycroft even identified a certain term in psychoanalysis - the 'therapeutic alliance', which is interpreted as an agreement on mutual trust. 
We support L. Filonchenko's opinion that clients have so-called 'barriers to openness', that is, conversations are conducted around secondary factors that are not an actual reason for counseling [4]. If the pharmacist finds the opportunity to identify hidden motives, the client quickly takes a 'step forward' and responds willingly to pharmacist's frankness. However, this requires patience and time. The ethical personality of the pharmacist is always mediated by personal qualities, and ultimately - this is the highest characteristic of the pharmacy worker.

The connection of the psychological problem and the situation is one of the characteristic differences between counseling and psychotherapy. Therefore, the main point in the counseling is the analysis of the problematic situation. However, a pharmacist needs to understand what adaptive capabilities of a client can be actualized. Because of this, most research efforts are aimed at identifying those characteristics, based on which we could argue how given norm of behavior (morality) is used by future pharmacists (O. Ambrosimov, D. Boychuk, A. Verbytsky, G. Vyshar, O. Gutorov, V. Petrenko, K. Rudestam, etc).

In the psychological and pedagogical literature, we can find various signs of the criteria of moral upbringing, which are directly related to future pharmacists, namely: positive attitude to work, people; active life position; direction and level of development of socially significant personal qualities. The use of these signs makes it possible for person to form certain levels of world view; develop its intellectual, behavioral and ethical criteria.

Intellectual criteria include knowledge of relevant moral norms and regulations, the ability to express moral judgments based on this knowledge. Behavioral criteria include ability to resist various temptations to violate generally accepted rules of life. And moral criteria contain feelings of guilt in case of violation of the rules. These signs are general criteria of moral upbringing. Based on the above characteristics we can set individual moral development criteria during training and education in a medical university. Among the criteria of general moral upbringing we identified those that are essential to future pharmacists: deep understanding and knowledge of the morality rules and regulations; the degree of development and formation of moral skills and behavioral habits; the nature of moral guidance in difficult situations; humanistic personal traits; favorable treatment of customers, the level of dignity, honor, conscience, etc. The above criteria allow us to grasp not only the result of pharmacist's moral development, but also motivation, goals and ways to achieve it. We hold the opinion that the criteria of moral upbringing are quite numerous and they do not represent a certain system. Not all criteria allow us to assess the moral sphere of the individual as an integral psychological entity. To construct a system of criteria for moral upbringing, it is necessary to take into account a number of requirements, to solve a number of problems. It is necessary to determine the needed and sufficient number of criteria that would cover the important aspects of moral upbringing of pharmacists. In order to streamline and systematize the defined criteria, it is necessary to investigate their interconnection, influence, to reveal their weight.

Conclusion. The moral development of future pharmacists involves not only the assimilation of norms, but also the standardization, the degree and nature of which may be a criterion for the level of moral self-activity. The above fact cannot but change the understanding of the very essence of moral upbringing, as well as one of its essential manifestations - a moral choice. New tones are introduced in understanding of the moral choices of future pharmacists, which makes it possible to determine the motives of their behavior. These tones may be immediate causes of action, but not final reasons. When working with a client, pharmacists should find out what needs and interests are the client's motive. All this leads to the conclusion that moral motivation is not a simple sum of various motives, but is a steering and organizing system, and the moral selection of motives depends on the main sense-forming motives that form this system. It is possible to reveal the true sense of the motives which guides the future pharmacist only by studying the interaction of his behavior with the behavior of the social environment, as well as various motives connected with each other. It is this approach that opens up the opportunity for a true individuality of future pharmacists who will have their own position in relation to moral norms that are directed at the basic moral values of society.

Practice proves that the lack of opportunities for further moral development inevitably leads to the degradation of the individual, forces return to the lower, negative levels of consciousness. Future pharmacists must be intelligent, be friendly. To support and stimulate highly-skilled pharmacists is a matter of unconditional importance, and the amount of money and efforts to solve this problem today will determine the appropriate percentage of our prosperity in the future.

\section{СПИСОК ВИКОРИСТАНИХ ДЖЕРЕЛ ТА ЛІТЕРАТУРИ}

1. Алехіна Н. Соціальний інтелект в структурі соціальної компетентності фахівців фармації / Н. Алехіна // Вісник Харківського національного університету імені В. Н. Каразіна. - Х., 2013. - С. 60-63.

2. Бондаренко О. Психологічна допомога особистості : [навчальний посібник для студентів старших курсів психологічних факультетів університетів] / О. Бондаренко. - Х., 2006 - 206 с.

3. Тернова О. Науково-методичне обгрунтування впровадження принципів біоетики в професійно-навчальну та практичну діяльність провізорів і фармацевтів : автореф. дис. на здобуття наук, ступеня канд. фарм. наук : спец. 15.00.01 "Технологія ліків, організація фармацевтичної справи та судова фармація" / О. Тернова. - К., $2010-24 \mathrm{c}$

4. Філонченко Л. Психологічні аспекти встановлення соціальних контактів між особами / Л. Філонченко. Луцьк, $2014-40 \mathrm{~s}$. 


\section{REFERENCES (TRANSLATED \& TRANSLITERATED)}

1. Alekhina N. Sotsial'nyi intelekt $v$ strukturi sotsial'noi kompetentnosti fakhivtsiv farmatsii [Social Intellect in the Structure of Social Competence of Druggists] / N. Alekhina // Visnyk Kharkivskoho natsional'noho universytetu im. V. N. Karazina [The Journal of V. N. Karazin Kharkiv National University]. - Kh., 2013. - S. 60-63.

2. Bondarenko O. Psykholohichna dopomoha osobystosti [Personal Psychological Support] : [navchal'nyi posibnyk dlia studentiv starshykh kursiv psykholohichnykh fakul'tetiv universytetiv] / O. Bondarenko. - Kh., $2006-206 \mathrm{~s}$.

3. Ternova O. Naukovo-metodychne obgruntuvannia vprovadzhennia pryntsypiv bioetyky v profesiino-navchal'nu ta praktychnu diial'nist provizoriv i farmatsevtiv [Scientific and Methodological Substantiation of Bioethical Principles Introduction in Vocation Education and General Practice of Pharmaceutists and Pharmacists] : avtoref. dys. na zdobuttia nauk, stupenia kand. farm. nauk: spets. 15.00.01 "Tekhnolohiia likiv, orhanizatsiia farmatsevtychnoi spravy ta sudova farmatsiia" / O. Ternova. - K., $2010-24$ p.

4. Filonchenko L. Psykholohichni aspekty vstanovlennia sotsial'nykh kontaktiv mizh osobamy [Psychological Aspects of Socializing between Persons] / L. Filonchenko. - Luts'k, 2014 - 40 s.

\section{Афанасенко О. В. Аспекти морального виховання у структурі навчання майбутніх провізорів.}

Мораль, як форма суспільної свідомості, є сукупністю принщипів, вимог, норм і правил, щчо регулюють поведінку людини у всіх сферах професійного та суспільного життя. У статті розглянуті аспекти морального виховання і якостей особистості майбутнього провізора. Моральний розвиток майбутніх провізорів передбачає не тільки момент засвоєння норм, а й момент нормотворення, ступінь $і$ характер якого може бути критерісм рівня моральної самоактивності. Вказаний факт не може не змінювати $i$ розуміння самої сутності моральної вихованості, а також одного із суттєвих моментів ї̈ прояву морального вибору. Визначено зміст і завдання морального виховання, охарактеризовано комплекс морально-етичних якостей майбутніх спеціалістів, які формуються у прочесі професійної підготовки, визначено особливості моральної мотивації майбутніх провізорів. Автор статті пропонує та аналізує навчальні технології формування професійної моральної вихованості.

Ключові слова: моральність, вихованість, самоактивність, соціальний інтелект, критерії моральної вихованості.

\section{Афанасенко О. В. Аспекты морального воспитания в структуре обучения будущих провизоров.}

Мораль, как форма общественной сознательности, являет собой совокупность принципов, требований, норм и правил, регулирующих поведение людей во всех сферах профессиональной и общественной жизни. В статье рассматриваются аспекты морального воспитания качеств личности будущего провизора. Моральное развитие будущзи провизоров предполагает не только момент усвоения норм, а и момент нормотворчества, степень и характер которого может быть критерием уровня моральной самоактивности. Указанный факт не может не менять и понимание самой сущности морального воспитания, а также одного из существенных моментов его проявления - морального выбора.

Определень содержание и задачи морального воспитания, охарактеризован комплекс моральноэтических качеств будущих спещиалистов, формулирующиеся в прочессе профессиональной подготовки, обозначены особенности моральной мотивации будущцих провизоров. Автор статьи анализирует и предлагает научные технологии формирования профессионального морального воспитания.

Ключевые слова: моральность, воспитание, самоактивность, сочиильньй интеллект, критерии морального воспитания. 